\title{
Acute oromucosal and palmar desquamation: a severe cutaneous adverse reaction to amphotericin and metronidazole
}

\author{
Ryan Connolly, Samantha Russell
}

Department of General Surgery, Mater Hospital, Belfast, UK

\section{Correspondence to} Dr Ryan Connolly, rconnolly06@qub.ac.uk

Accepted 28 May 2014
CrossMark

To cite: Connolly $\mathrm{R}$ Russell S. BMJ Case Rep Published online: [please include Day Month Year] doi:10.1136/bcr-2014205501

\section{DESCRIPTION}

A 48-year-old man was started on intravenous amphotericin and metronidazole to treat sepsis in the postoperative period following the repair of a perforated duodenal ulcer. Over a 1 week period he subsequently developed acute epithelial desquamation affecting the oral mucosa (figure 1) and palmar aspects of both hands (figure 2).

Subsequent treatment involved the immediate discontinuation of all non-essential medications including amphotericin and metronidazole and symptomatic relief with the application of regular topical emollients. This resulted in the rapid resolution of symptoms, thereby supporting the diagnosis of a severe cutaneous adverse drug reaction to amphotericin and metronidazole.

\section{DISCUSSION}

Systemic antibiotic therapy is a major cause of severe cutaneous adverse reactions-a spectrum of mucocutaneous hypersensitivity disorders including Stevens-Johnson syndrome and toxic epidermal necrolysis. ${ }^{1}$ Although the exact pathogenesis is not fully understood as yet, these rare but lifethreatening disorders are thought to result from cytotoxic T-lymphocyte-mediated keratinocyte apoptosis in genetically predisposed patients. ${ }^{2} 3$ Severe cases are at further risk of developing

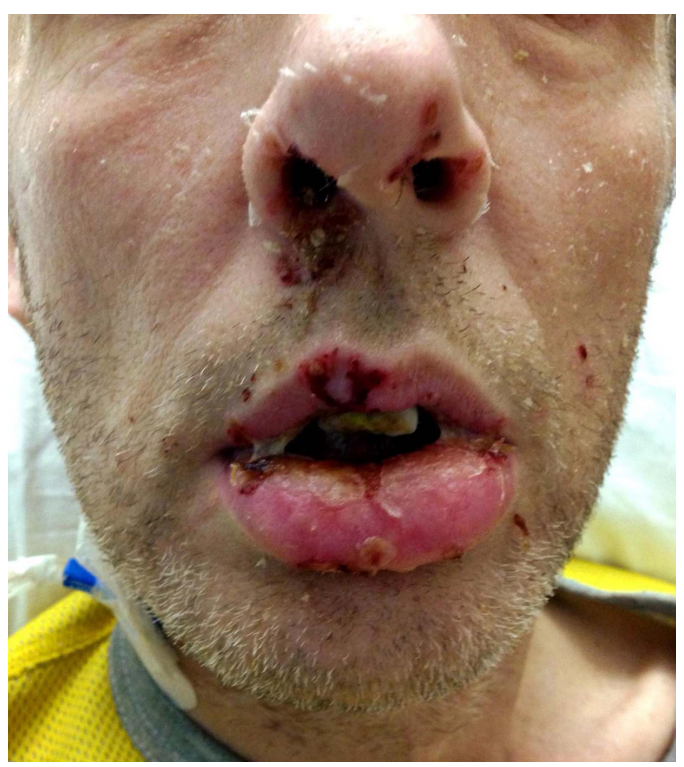

Figure 1 Exudative desquamation affecting oromucosal and nasal epithelium.

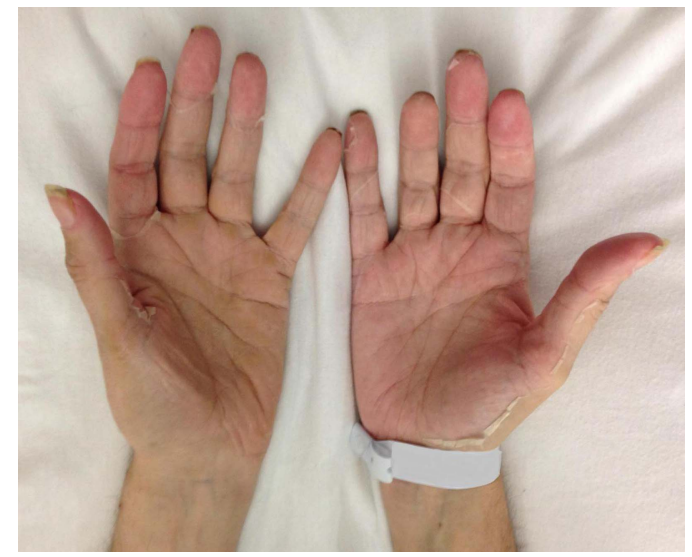

Figure 2 Epithelial desquamation affecting the palmar aspect of both hands.

systemic manifestations including renal failure and cardiac compromise.

Despite this patient's underlying morbidity, the selection of an alternative antibiotic and antifungal regimen resulted in the effective treatment of his postoperative sepsis without further precipitation of cutaneous hypersensitivity reactions. He subsequently made a full clinical recovery.

\section{Learning points}

- Given their potentially life-threatening nature, clinicians must maintain a high index of suspicion for drug-induced hypersensitivity reactions, thereby ensuring their prompt recognition and appropriate management.

- A detailed medication history should be ascertained in all patients presenting with acute mucocutaneous symptoms.

Competing interests None.

Patient consent Obtained.

Provenance and peer review Not commissioned; externally peer reviewed.

\section{REFERENCES}

1 Roujeau JC. Clinical heterogeneity of drug hypersensitivity. Toxicology 2005:209:123-9.

2 Wolf $R$, Orion E, Marcos B, et al. Life-threatening acute adverse cutaneous drug reactions. Clin Dermatol 2005;23:171-81.

3 Harr T, French LE. Toxic epidermal necrolysis and Stevens-Johnson syndrome. Orphanet J Rare Dis 2010:5:39. 


\section{Images in...}

Copyright 2014 BMJ Publishing Group. All rights reserved. For permission to reuse any of this content visit http://group.bmj.com/group/rights-licensing/permissions.

BMJ Case Report Fellows may re-use this article for personal use and teaching without any further permission.

Become a Fellow of BMJ Case Reports today and you can:

- Submit as many cases as you like

- Enjoy fast sympathetic peer review and rapid publication of accepted articles

- Access all the published articles

- Re-use any of the published material for personal use and teaching without further permission

For information on Institutional Fellowships contact consortiasales@bmjgroup.com

Visit casereports.bmj.com for more articles like this and to become a Fellow 